\title{
IAMJ
}

INTERNATIONAL

AYURVEDIC

MEDICAL JOURNAL

Review Article

ISSN: 23205091

Impact Factor: 5.344

\section{A CONCEPTUAL STUDY AT EFFECT OF RITU ON AGNI.}

\section{Shubham Shukla ${ }^{1}$, Rajesh Sharma ${ }^{2}$, Dinesh Chandr Sharma ${ }^{3}$}

${ }^{1}$ P.G. Scholar, Deptt. of Kriya Sharir, U.C.A Jodhpur, Rajasthan, India

${ }^{2}$ Associate professor and H.O.D, Deptt. of Kriya Sharir, U.C.A Jodhpur, Rajasthan, India

${ }^{3}$ Assistant professor, Deptt. of kriya Sharir, U.C.A Jodhpur, Rajasthan, India

\section{Corresponding Author: sony.shukla56@gmail.com}

\section{https://doi.org/10.46607/iamj2508112020}

(Published online: November 2020)

Open Access

(C) International Ayurvedic Medical Journal, India 2020

Article Received: 23/10/2020 - Peer Reviewed: 06/11/2020 - Accepted for Publication: 16/11/2020

Check for updates

\section{ABSTRACT}

The ancient Indian medical science Ayurveda describe various core concept related to the physiological functioning and biological response; Agni and Ritu are such concept. These concepts are not only helpful maintain health in a person but also cure disease. Agni gives power to our body by performing digestion and assimilation of food. Jatharagni, Bhutagni and dhatvagni contributes digestive and metabolic activities of absorbed food. Samagni gives Arogya, Ayu, Bala, Swasthyam, Varnam, Utsaha, oja, prabha and teja to the body which all are mirror physical and mental State ${ }^{1}$. Agni dushti is one of premier causative factor for many diseases so Agni play important role in understanding of disease prognosis, pathogenesis, diagnosis establishment of treatment protocol. In human being Agni also affected by various such as Ritu, Aahar etc. This article emphasized conceptual understanding of Agni and its variation according to Ritu.

Keywords: Ayurveda, Agni, Jatharagni, Ritu.

\section{INTRODUCTION}

According Ayurveda human body is combination of Panchmahabhoot (Five fundamental element like Earth, Jala, Agni, Vayu and Akaash $)^{2}$ always undergoes "wear and tear" phenomena due to daily activities thus two process are constantly going in our body Chaya - Apchaya. Balance of these process not only keep Dhatu (basic tissue) and Dosha in equilibrium but also keep disease away. For this continuous process of 
yielding energy or Dhatu formation, an inheritance factor exists, In Ayurveda called as Agni. It is premier Factor in maintain of human life. Concept of Agni is one of the core concepts of Ayurveda. There is various factor which effect body equilibrium by doing Dosha imbalance which leads to Agni imbalance. In other hand Ayurveda also consider "whatever is found in universe also present in human body"3 which means our environment also effect on our body. Human body try to maintain normal state of Dosha and Agni by resistant environmental change, here our Ritucharya help to body also by maintaining Dosha which leads to maintain our Agni.

Aim and Object: - To understand correlation between Agni and Ritu.

\section{Material and methods: -}

Review of literature related Agni and Ritu are Collected from Brihatrayi and available commentaries on it and research article are also searched from various websites.

Type of study: - Conceptual study.

Concept of Agni: - Agni means various factor which participate and regulates digestion and metabolism in a living tissue by pakadi karmas. All function of Agni can be summed in two types - Dhatu Nirmana (tissue formation) and Dhatu karma (tissue function). Agni indicates form of energy which is always a functional unit not structural unit although Ayurveda consider Agni is situated in pitadhara kala (situated between Amashya and Pakvashya) also name Grahni ${ }^{4}$.In concept of Dosh - Dhatu - Mala of Ayurveda, function of Agni are consider property of pitta. Achraya Marich said "Agni in the form of Pitta gives rise to prosperous or adverse outcome in body as per its normal or abnormal state" but Chakrpani has clarified that "the above statement only refers to phenomena of heat associated with pitta" . Agni is delivering its functions not only under the influence Pitta but Also other Dosha or factor. Agni is divided basically in three types: Jatharaagni, Bhootaagni and Dhatvaagni ${ }^{6}$. Jatharaagni is also named Kayaagni, Koshtaagni or Pachakaagni. Jatharaagni has main function of Dhna and Paka which result food divided in two parts Sarabhaga (nutrients) and Kittabhaga (Mutra, Purisha, Sweda). Unless the Sarabhaga produced by Jatharaagni is qualitative, it will not be able for further process of Bhutaagni and Dhatvaagni paka. Hence Jatharaagni is important for better functioning of others Agni in human body ${ }^{7}$.

Concept of Ritu: - Ritu word is derived from word Rtú Which means is fixed or appointed time, this in turn comes from the word Rta as used in Vedic Sanskrit literally means "order or course of things". The year; Sanvatsara is divide in two Kaal called Ayana depending on the direction of sun's movement. For example, "Uttarayana (northern solstice)" and "Dakshinayana (sothern solstice) $)^{8}$. Uttarayana called Adankaal and Dakshinayan. Each of Ayana are formed three Ritus i.e seasons. Each Ritu is divided into two months.

A year consists six seasons ${ }^{9}$ and 12 month which names are below: -

\begin{tabular}{|c|l|l|l|}
\hline S.NO. & Ritu name & Another name of Ritu & \multicolumn{1}{|c|}{ Months name } \\
\hline 01 & Shishir Ritu & Extreme winter / Dewy season & Magha and phalguna \\
\hline 02 & Basant Ritu & Spring season & Chaitra and Vaishakha \\
\hline 03 & Grishm Ritu & Summer season & Jyeshtha and Ashadha \\
\hline 04 & Varsha Ritu & Monsoon season & Shravana and bhadrapada \\
\hline 05 & Sharad Ritu & Autumn season & Ashwina and Kartika \\
\hline 06 & Hemant Ritu & Prewinter season & Margashirsha and Pausha \\
\hline
\end{tabular}

Acharya Vagbhatt called the period between two Ritu as the Ritu sandhi Kaal. The last week of the first season and the first week of the coming season are called the Ritu Sandhi Kaal. In this way, there are six seasons junction period as well as six seasons.
Effect of Ritu on Agni: - Due to change of Ritu our surrounding environment also change which effects our body Agni.

These effects are: - 
1. Varsha Ritu: - IN the period of Aadankaal weak human body, vapor from land, rainfall and Amla Vipaka of water make Agni weak ${ }^{10}$.

2. Sharad Ritu: - Commonly this season Pitta is increased situation in human body ${ }^{11}$. In this Ritu, Agni also weakens due to the liquid property of Pitta $^{12}$.

3. Hemant Ritu: - During this Ritu, the coldness is more, so the Agni becomes strong in healthy person due to the stoppage of the ignition by touch of cold air $^{13}$.

4. Shishir Ritu: - According to Ayurveda Shishir Ritu has similar feature as Hemant Ritu Although it has more coldness then Hemant Ritu ${ }^{14}$. Due to coldness Agni is also stronger in this Ritu.

5. Basant Ritu:- The Kapha accumulated during Hemant Ritu is stimulated by the rays of sun in this Ritu and makes Agni weak ${ }^{15}$.

6. Grishm Ritu: - In this Ritu the sun absorbs snigdha ansh of the world with its rays ${ }^{16}$ due to which, the Jaliy dhatu in the body, i.e. Kapha also begins to decay and the Vayu vridhi starts ${ }^{17}$. Heat of sunlight and our body weakness can destroy our Agni so we should take liquid, snigdh, Madhura rasa, Sheet viry Anna. These things preserve our body and Agni from heat.

Ritu Sandhi Kaal: - At this time, one season is ending, and the second season starts, so during this period, symptoms of both seasons are present in the environment which also affects our body Agni. At this time, changes in the atmosphere and body also lead to change in the Agni, either this change weakens or increases the Agni according to the coming season.

\section{DISCUSSION}

So, it is concluded that Agni and Ritu are correlated with each other. Agni has prime role in keeping DoshDhatu - Mala balance. Improper Agni is one of core reason to rise a disease in human. Life, complexion, strength, health, ebullience, splendor, oja, body Temperature and vitality all depend on normal state of Agni. Proper maintain of Agni leads to along healthy life and its impairment give diseased state by disturbed metabolism which leads to death. Agni and Dosha are influenced by Ritu and they have different states in different Ritu. Our Acharyas have described a dietary sanctuary according to the seasons in Ayurveda, so that the effect of changes in the climate due to the seasons is minimal to us Thus we should take following some of these Ahara for maintain our Agni.

1. Varsha Ritu: - Honey should be used with all meals. Use of sour salt and balsamic food as food. Old wheat and Raktshaali rice should be consumed with Sanskrit yush.

2. Sharad Ritu: - Hansodak should be drunk as water. In this Ritu, Madhur, Laghu, Tikt Rasa head food should be consumed.

3. Hemant Ritu: - Consumption of Snigdh, Amla, and lavan food should be taken during the Hemant Ritu. During Hemant season, milk and substances made from it, Ikshu Vikar, fat, oil, rice and hot water should be consumed.

4. Shishir Ritu: - In this Ritu, you should take a diet like the Hemant Ritu i.e, Consumption of Snigdh, Amla, and lavan food should be taken during the Shishir Ritu. During Shishir Ritu, milk and substances made from it, Ikshu Vikar, fat, oil, rice and hot water should be consumed.

5. Basant Ritu: - In this season, Guru, Amla rasa, Snigdh and Mdhur food should be consumed.

6. Grishm Ritu: - Madhur, Sheetal Drav and balsamic food should be consumed during this season. Sattu mixed with sugar and water, Ghee, milk and rice of Shaali Bhaat should be consumed.

Ritu Sandhi Kaal: - In Ritu Sandhi one should bit by bit start rejecting let go practices of the previous Ritu including the practices related to dietetic practice, lifestyle and behavior. At the same time, he should bit by bit start practicing and adapting to the practices of the upcoming Ritu again including diet, lifestyle and behavioral practices of the Ritu in coming. The practices should be adapted in a step ladder pattern, so should the let going process. Practicing anything or letting go anything suddenly is not easy. The body does not tolerate when anything is implemented out of regular practice or withdrawn from regular practice all of a sudden. For example, giving off the practice of alcohol consumption suddenly is difficult. It may be done suddenly but 
it will create serious impact on our body health and Agni, including withdrawn symptoms.

Proper state of Agni is necessary for healthy person so we should follow Ritucharya to maintain it.

\section{CONCLUSION}

Whole process of digestion and metabolic activity of human body work with the help of biological fire known as Agni in Ayurveda. There are various factors which effect Agni which can leads improper digestion. Improper digestion does not nourish and repair to body cell, this phenomenon leads to our body death thus longevity and strength of life depends on healthy status of Agni, it should be maintained by suitable diet and behavior.

\section{REFERENCES}

1. Chaturvedi G, Pandey K, editor, (1st Ed.). Charak Samhita of Agnivesha Vol-2, chikitsasthana; grahanidoshchikitsa: Chapter15, verse 3-4. Varanasi: Chaukhambha Vishvabharti Prakashana, Reprint 2017; Page no 425.

2. 2.Shastri AD, editor, (1st Ed.). Vol-1, Sushruta Samhita of Sushruta, Sutrasthana; Annapanvidhi Adhyaya: Chapter 46, verse 533. Varanasi: Chaukhambha Sanskrit Sansthan, reprint 2017; page no 290.

3. Chaturvedi G, Pandey K, editor, (1st Ed.). Charak Samhita of Agnivesha Vol-1, Sharirsthana; Mahatigarbhavkranti Adhyay: Chapter 4, verse 13. Varanasi: Chaukhambha Vishvabharti Prakashana, Reprint 2017; Page no. 871

4. Chaturvedi G, Pandey K, editor, (1st Ed.). Charak Samhita of Agnivesha Vol-2, chikitsasthana; grahanidoshchikitsa: Chapter15, verse 56. Varanasi: Chaukhambha Vishvabharti Prakashana, Reprint 2017; page no 462

5. Chaturvedi G, Pandey K, editor, (1st Ed.). Charak Samhita of Agnivesha Vol-1, Sutrasthana; Vatakalakaliy Adhyay: Chapter12, verse 11. Varanasi: Chaukhambha Vishvabharti Prakashana, Reprint 2017; page no 251

6. Chaturvedi G, Pandey K, editor, (1st Ed.). Charak Samhita of Agnivesha Vol-2, chikitsasthana; grahanidoshchikitsa: Chapter15, verse 38. Varanasi: Chaukhambha Vishvabharti Prakashana, Reprint 2017; page no 459

7. Chaturvedi G, Pandey K, editor, (1st Ed.). Charak Samhita of Agnivesha Vol-2, chikitsasthana; grahanidoshchikitsa: Chapter15, verse 39-40. Varanasi: Chaukhambha Vishvabharti Prakashana, Reprint 2017; page no 459

8. Chaturvedi G, Pandey K, editor, (1st Ed.). Charak Samhita of Agnivesha Vol-1, Sutrasthana; Tasyashitiy Adhyay: Chapter 6, verse 4. Varanasi: Chaukhambha Vishvabharti Prakashana, Reprint 2017; page no 134
9. Shastri AD, editor, (1st Ed.). Vol-1, Sushruta Samhita of Sushruta, Sutrasthana; Ritucharya Adhyaya: Chapter 6, verse 6. Varanasi: Chaukhambha San-skrit Sansthan, reprint 2017; page no28.

10. Chaturvedi G, Pandey K, editor, (1st Ed.). Charak Samhita of Agnivesha Vol-1, Sutrasthana; Tasyashitiy Adhyay: Chapter 6, verse 33. Varanasi: Chaukhambha Vishvabharti Prakashana, Reprint 2017; page no 143

11. Chaturvedi G, Pandey K, editor, (1st Ed.). Charak Samhita of Agnivesha Vol-1, Sutrasthana; Tasyashitiy Adhyay: Chapter 6, verse41. Varanasi: Chaukhambha Vishvabharti Prakashana, Reprint 2017; page no 145

12. Chaturvedi G, Pandey K, editor, (1st Ed.). Charak Samhita of Agnivesha Vol-2, chikitsasthana; grahanidoshchikitsa: Chapter15, verse 65. Varanasi: Chaukhambha Vishvabharti Prakashana, Reprint 2017; page no 463

13. Chaturvedi G, Pandey K, editor, (1st Ed.). Charak Samhita of Agnivesha Vol-1, Sutrasthana; Tasyashitiy Adhyay: Chapter 6, verse 4. Varanasi: Chaukhambha Vishvabharti Prakashana, Reprint 2017; page no 134

14. Chaturvedi G, Pandey K, editor, (1st Ed.). Charak Samhita of Agnivesha Vol-1, Sutrasthana; Tasyashitiy Adhyay: Chapter 6, verse 19. Varanasi: Chaukhambha Vishvabharti Prakashana, Reprint 2017; page no 141

15. Chaturvedi G, Pandey K, editor, (1st Ed.). Charak Samhita of Agnivesha Vol-1, Sutrasthana; Tasyashitiy Adhyay: Chapter 6, verse 22. Varanasi: Chaukhambha Vishvabharti Prakashana, Reprint 2017; page no 141

16. Chaturvedi G, Pandey K, editor, (1st Ed.). Charak Samhita of Agnivesha Vol-1, Sutrasthana; Tasyashitiy Adhyay: Chapter 6, verse 27. Varanasi: Chaukhambha Vishvabharti Prakashana, Reprint 2017; page no 142

17. Tripathi B. Dr, editor, ( $1^{\text {st }}$ Ed.). Astanga Hridayam of Srimadvagbhata, Strasthana; Ritucharya Adhyay: Chapter 3, verse 27. Delhi: Chaukhambha Sanskrit Pratishthan, Reprint 2011; page no 46

\section{Source of Support: Nil \\ Conflict of Interest: None Declared}

How to cite this URL: Shubham Shukla et al: A Conceptual Study At Effect Of Ritu On Agni. International Ayurvedic Medical Journal \{online\} 2020 \{cited November, 2020\} Available from: http://www.iamj.in/posts/images/upload/5121 5124.pdf 